\title{
Vegetative propagation of Nidularium fulgens Lem. in vitro*
}

\author{
R. L. M. Pierik and H. H. M. Steegmans \\ Department of Horticulture, Agricultural University, P.O. Box 30, 6700 AA Wa- \\ geningen, Netherlands
}

Received 21 March 1984; accepted 2 April 1984

Key-words: in vitro, vegetative propagation, axillary branching, Nidularium fulgens Lem.

\section{Summary}

Shoots of Nidularium fulgens Lem. were isolated on solid media. Shoots which started to grow were transferred to liquid media placed on a rotator, to study axillary branching. Axillary formed sprouts were subsequently rooted in vitro or in the soil. The resulting plants were uniform, as no callus and/or adventitious buds were formed during this procedure.

\section{Introduction}

Nidularium fulgens Lem., Bromeliaceae, is a rather unknown but very attractive acaulescent pot plant which originates from Brazil. It is a species with bright green sharply toothed leaves, usually copiously mottled with dark green spots. At flowering time the collaret of shortened inner leaves turns to a brilliant scarlet colour. The flowers are formed in the centre of the rosette and sometimes in the axils of the coloured inner leaves (Padilla, 1973).

Vegetative propagation of Nidularium fulgens in vivo, by using cuttings of the axillary developing shoots, is too slow and propagation from seed is impossible. Since no literature pertaining to the propagation in vitro of Nidularium could be found, such a method was developed and described in this paper.

\section{Material and methods}

Shoot tips were isolated from axillary formed shoots located at the bases of a few flowering Nidularium fulgens Lem. plants. After thorougly rinsing the shoots with soap, the outer leaves were removed. The shoots were then sterilized as follows: 30

* Publication 508. Department of Horticulture, Agricultural University, Wageningen, Netherlands. 
minutes in $10 \%$ commercial bleaching liquid and three times rinsing with sterile tap water during totally 30 minutes. A magnetic stirrer was used during this procedure. Then, a few of the outer primordial leaves were peeled off aseptically and also a small part of the shoot base was removed. Shoot tips $(3-5 \mathrm{~mm})$ were then transplanted to the following medium: MS (Murashige \& Skoog, 1962) macroelements at half strenth, NaFeEDTA $25 \mathrm{mg} \mathrm{l}^{-1}$, sucrose $3 \%$, nicotinic acid $5 \mathrm{mg} \mathrm{l}^{-1}$, vitamin $\mathrm{B}_{1} 5 \mathrm{mg} \mathrm{l}^{-1}$, pyridoxine $0.5 \mathrm{mg} \mathrm{l}^{-1}$, glycine $4 \mathrm{mg} \mathrm{l}^{-1}$, méso-inositol $100 \mathrm{mg} \mathrm{l}^{-1}$, BA (6benzylaminopurine) $1 \mathrm{mg} \mathrm{l}^{-1}$, NAA (naphthaleneacetic acid) $0.1 \mathrm{mg} \mathrm{l}^{-1}$ and Difco Bacto agar $0.8 \%$. The $\mathrm{pH}$ was adjusted to 6.0 before autoclaving. The vitamin mixture was chosen according to Mekers (1977).

One month after the isolation of the shoots, when they started to grow, the noninfected ones were transferred to a liquid medium (no agar) with BA lowered to 0.3 $\mathrm{mg} \mathrm{l}^{-1}$ ) (see 'Results'). The liquid medium was chosen to promote axillary branching. The medium, $30 \mathrm{ml}$, was contained in $100-\mathrm{ml}$ Erlenmeyer flasks covered with aluminium foil (Fig. 1), and placed on a rotator (under an angle of $45^{\circ}$ ) at $3 \mathrm{rpm}$. By subculturing the axillary formed shoots in liquid media 4 times, axillary branching increased, and subsequently the experiment as described in Table 1 was started.

The axillary formed shoots thus obtained were rooted in soil or in test tubes on a solid medium, as described before, except: MS macroelements at full strength, sucrose $4 \%$, no BA, and NAA in variable concentrations (see Results). Rooting in soil took place without auxin pre-treatment. The soil mixture was sand, compost and peat (1:1:1 by volume).

Unless stated otherwise, test tubes and rotator were placed in a culture room at $25^{\circ} \mathrm{C}$, and illuminated with Philips fluorescent tubes (TL $40 \mathrm{~W} / 27,8 \mathrm{~W} \mathrm{~m}^{-2}$ ). Daylength was $16 \mathrm{~h}$.

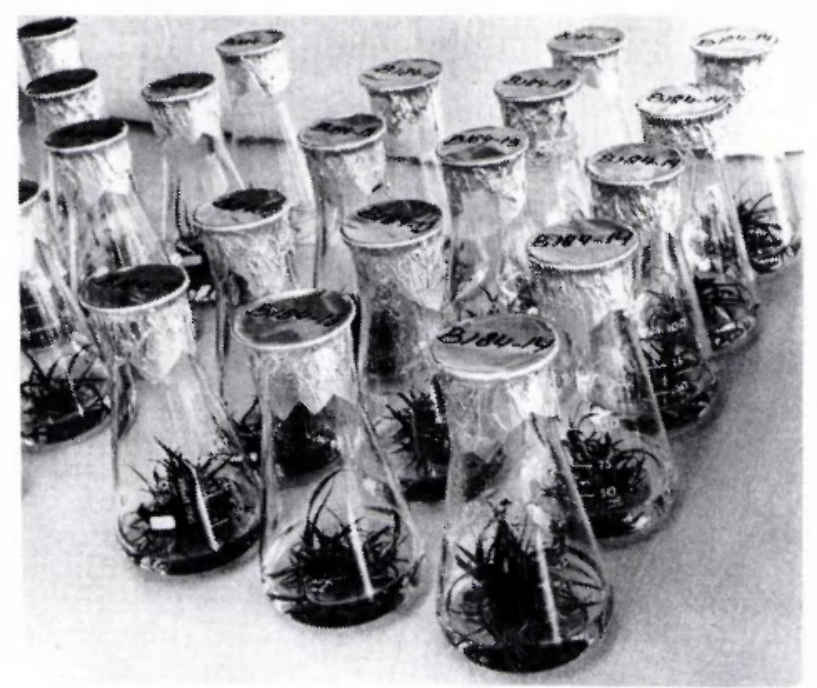

Fig. 1. Shoot multiplication through axillary branching in liquid media. 
Experiments on axillary branching lasted 12 weeks, whereas rooting experiments were stopped after 8 weeks.

\section{Results}

Start of growth and axillary branching of excised shoots

As soon as the excised shoots started to grow on the solid medium with $1 \mathrm{mg} \mathrm{l}^{-1} \mathrm{BA}$ (this relatively high concentration was chosen to activate initial growth), they were transferred into liquid media with a much lower BA level; this was done to avoid callus formation and/or adventitious bud formation, which are induced by high BA levels, and often lead to mutations in Bromeliaceae when propagated in vitro (Pierik, unpublished). It took 5 months in the first liquid medium before the axillary shoots had developed so far that they could be subcultured. However, in the next subcultures axillary branching gradually increased until after the fourth subculture a steady state was reached. From that moment on the experiments could be started.

\section{Axillary branching in liquid media}

Since nothing was known about the light requirements for axillary branching of $\mathrm{Ni}$ dularium the following preliminary experiment was done. Shoots were multiplied in continuous light of high intensity $\left(14 \mathrm{~W} \mathrm{~m}^{-2}\right)$ or at a daylength of $16 \mathrm{~h}$ at low light intensity $\left(8 \mathrm{~W} \mathrm{~m}^{-2}\right)$. This experiment showed that shoot multiplication and sprout quality were much better at $16 \mathrm{~h}$ and $8 \mathrm{~W} \mathrm{~m}^{-2}$. Therefore, all subsequent experiments were done under these low light conditions.

Another preliminary experiment showed that shoot multiplication (as judged by the mean number of axillary shoots per shoot and by the mean shoot fresh weight produced per isolated shoot) was drastically reduced on a stationary liquid medium as compared with a rotating liquid medium. Therefore, the following experiments were done in a rotating medium.

The influence of various factors on shoot multiplication is given in Table 1. A comparison of shoot multiplication at various MS levels (upper part of Table 1) shows that the mean number of axillary shoots per shoot and the mean fresh weights increased when the MS concentration was increased, with the highest values at MS full strength; however, the strongest increase was observed at the first step from $1 / 4$ to $1 / 2 \mathrm{MS}$.

The sucrose experiment (Table 1, middle part) showed a similar pattern: an increase in shoot multiplication and fresh weight was reached by raising the sugar concentration from 1 to $4 \%$, with the highest mean fresh weight values at $4 \%$; however the mean fresh weight per axillary formed shoot at $4 \%$ (as compared with $3 \%$ ) decreased, because at that concentration the number of shoots was so high (7.7) that competition between shoots became evident.

The interpretation of the BA/NAA experiment (lower part of Table 1) is as follows:

1. The mean number of axillary shoots within each BA concentration was hardly affected by the variation in the NAA concentration: however this does not hold true for the mean fresh weights which are always the highest at $0.05 \mathrm{mg} \mathrm{l}^{-1}$ NAA. 
Table 1. Axillary branching in Nidularium fulgens Lem. as influenced by various factors. Duration of experiment 12 weeks. An asterisk means control treatment as described in the methods (MS macroelements $1 / 2$ strength, sucrose $3 \%$, BA $0.3 \mathrm{mg} \mathrm{l}^{-1}$, NAA $0.1 \mathrm{mg} \mathrm{l}^{-1}$ ). Totally 10 explants per treatment.

\begin{tabular}{|c|c|c|c|c|}
\hline Factor & Level & $\begin{array}{l}\text { Mean number of } \\
\text { axillary shoots } \\
\text { per shoot }\end{array}$ & $\begin{array}{l}\text { Mean fresh weight } \\
\text { (mg) produced per } \\
\text { isolated shoot }\end{array}$ & $\begin{array}{l}\text { Mean fresh weight } \\
\text { (mg)per axillary } \\
\text { formed shoot }\end{array}$ \\
\hline \multirow{4}{*}{$\begin{array}{l}\text { MS macro- } \\
\text { elements } \\
\text { (strength) }\end{array}$} & $1 / 4$ & 4.7 & 221 & 47 \\
\hline & $1 / 2^{*}$ & 5.2 & 411 & 79 \\
\hline & $3 / 4$ & 5.8 & 406 & 70 \\
\hline & full & 6.3 & 460 & 73 \\
\hline Saccharose & 1 & 3.1 & 195 & 63 \\
\hline \multirow{3}{*}{ concn. $(\%)$} & 2 & 4.4 & 273 & 62 \\
\hline & $3^{*}$ & 5.2 & 411 & 79 \\
\hline & 4 & 7.7 & 454 & 59 \\
\hline Growth & BA $0.1+$ NAA 0.01 & 4.8 & 240 & 50 \\
\hline regulators & BA $0.1+$ NAA 0.05 & 3.8 & 395 & 104 \\
\hline \multirow[t]{7}{*}{ concn. $\left(\mathrm{mg} \mathrm{l}^{-1}\right)$} & BA 0.1 + NAA 0.1 & 3.7 & 278 & 75 \\
\hline & BA $0.3+$ NAA 0.01 & 5.3 & 413 & 78 \\
\hline & BA $0.3+$ NAA 0.05 & 4.6 & 432 & 94 \\
\hline & BA $0.3+$ NAA $0.1^{*}$ & 5.2 & 411 & 79 \\
\hline & BA $0.6+$ NAA 0.01 & 7.5 & 510 & 68 \\
\hline & BA $0.6+$ NAA 0.05 & 8.0 & 544 & 68 \\
\hline & BA $0.6+$ NAA 0.1 & 7.4 & 466 & 63 \\
\hline
\end{tabular}

2. When the BA concentration was raised, the mean number of axillary shoots and the total fresh weight per isolated shoot were increased at all NAA concentrations. However, the mean fresh weight per shoot decreased when the BA concentration was increased from 0.3 to $0.6 \mathrm{mg} \mathrm{l}^{-1}$; this was due to competition between the numerous shoots at the highest BA level $\left(0.6 \mathrm{mg} \mathrm{1}^{-1}\right)$.

Axillary shoots formed on a medium with $0.6 \mathrm{mg} \mathrm{t}^{-1} \mathrm{BA}$ tended to be rather small (63-68 mg per shoot, Table 1) and some thickening at the bases of the shoots occurred. When these shoots were again subcultured on $0.6 \mathrm{mg} \mathrm{l}^{-1} \mathrm{BA}$, thickening increased and the beginning of callus formation was observed. Prolonged cultivation at this concentration should therefore be avoided.

The general conclusion is that axillary branching was optimal under the following conditions: daylength $16 \mathrm{~h}$, light intensity $8 \mathrm{~W} \mathrm{~m}^{-2}$, rotated liquid media, MS macroelements at full strength, sucrose $4 \%, \mathrm{BA} 0.6 \mathrm{mg} \mathrm{l}^{-1}$, NAA $0.05 \mathrm{mg} \mathrm{l}^{-1}$.

\section{Rooting and transfer to soil}

Since it was shown (Davidson \& Donnan, 1977; Hosoki \& Asahira, 1980) that NAA (in comparison with IAA and IBA) had the greatest effect on root initiation of shoots of several Bromeliaceae in vitro, NAA was chosen for a rooting experiment with axillary shoots of Nidularium fulgens. NAA was examined in the concentration range: 0 (control), $0.05,0.1,0.3,0.6,1.0 \mathrm{mg} \mathrm{l}^{-1}$. This experiment showed that 


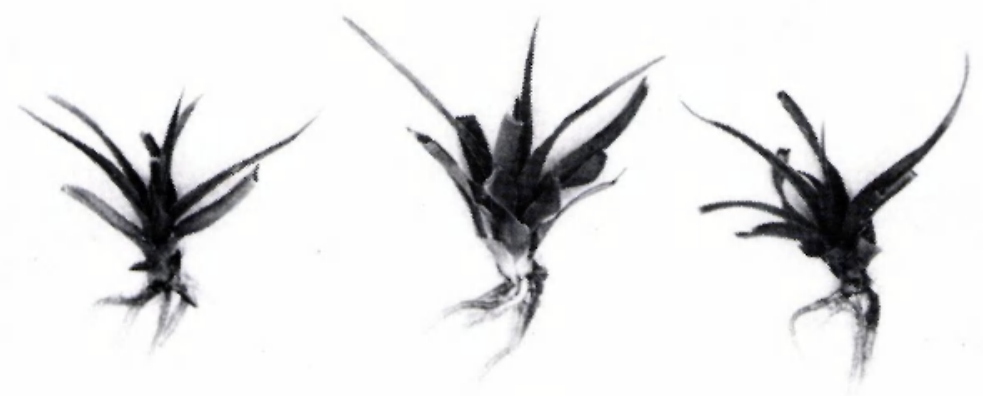

Fig. 2. Rooting of axillary shoots in vitro on a solid medium with $0.05 \mathrm{mg} \mathrm{l}^{-1} \mathrm{NAA}$. Photo taken 8 weeks after isolation.

in all treatments, even in the control the percentages of rooting were almost 100 . The mean number of root primordia per shoot, which was 2.8 in the control, increased to 3.3 at 0.05 (Fig. 2) and 0.1 and to 3.7 in the range $0.3-1.0 \mathrm{mg} \mathrm{l}^{-1} \mathrm{NAA}$. It can be concluded that shoots rooted very easily even without NAA in the medium, but the best root development was obtained with NAA at $0.05 \mathrm{mg} \mathrm{l}^{-1}$.

It appeared also possible to transfer shoots without roots to soil and to root them in vivo in the greenhouse. But is was necessary to keep the humidity high and the light intensity low to avoid dessiccation. Therefore a plastic cover was put over the plants for 3 weeks.

In about 100 plants left to grow in the greenhouse, no visible deviations from the original plants were observed and so a uniform offspring was obtained.

\section{Discussion and conclusions}

This study has shown that the start of axillary branching in excised shoots was very slow and that it took several subcultures before an appreciable number of axillary shoots was formed. We suppose that this is due to the fact that rejuvenation has to occur before the rate of axillary branching increases. With isolated meristems we might have obtained a more rapid rejuvenation; but now it took several subcultures to rejuvenate our starting material, which had been derived from adult plants. However, if we would have used meristem cultures, the chances to succeed would have been very small, because this technique is extraordinarily difficult and chances are that the plant material is lost as a result of enzymatic browning.

Although several factors affecting axillary branching were examined, we feel sure that the shoot multiplication rate can be increased further e.g. by using higher levels of MS macroelements (1/1) and sucrose $(4 \%)$ than mentioned in Table 1. Also other factors like rotation speed, volume of the media in the flasks, longitudinal splitting of the shoots (Pierik \& Steegmans, 1983), daylength, light intensity, temperature, etc. should be tested further to improve the shoot multiplication rate. However, it is not advised to raise the level of BA to promote axillary branching. 
Experiments with other Bromeliaceae e.a. Aechmea fasciata, Neoregelia carolinae tricolor and Guzmania hybrids (Pierik, unpublished) in vitro have shown that higher BA levels often lead to callus formation at the shoot bases, resulting in adventitious bud formation with a prevalence of genetically aberrant plants.

\section{References}

Davidson, S. E. \& A. Donnan, 1977. In vitro propagation of Cryptanthus ssp. Proceedings Florida State Horticultural Society 90: 303-304.

Hosoki, T. \& T. Asahira, 1980. In vitro propagation of bromeliads in liquid culture. Horticultural Science 15: 603-604.

Mekers, O.. 1977. In vitro propagation of some Tillandsioideae (Bromeliaceae). Acta Horticulturae 78 : $311-320$

Murashige, T. \& F. Skoog, 1962. A revised medium for rapid growth and bio-assays with tobacco tissue cultures. Physiologia Plantarum 15: 473-497.

Padilla, V., 1973. Bromeliads. Crown Publishers Inc., New York.

Pierik, R. L. M. \& H. H. M. Steegmans, 1983. Vegetative propagation of a chimaerical Yucca elephantipes Regel in vitro. Scientia Horticultural 21: 267-272. 